\title{
当院における大腿骨転子部骨折手術のクリティカルパス
}

\author{
藤 原 稔 史* 佛 坂 俊 輔* 井 上 三四郎* \\ 前隆男* 力丸俊 一* 野口康 男*
}

\section{Critical Pathways for Trochanteric Fractures of the Femur}

Toshifumi Fujiwara*, Shunsuke Hotokezaka*, Sanshiro Inoue*, Takao Mae*, Shunichi Rikimaru*, and Yasuo Noguchi*

【はじめに】大腿骨転子部骨折は歩行状態，合併症の有無などによるバリアンスが生じやすく，画一的な パスでは逸脱，脱落をするケースが多い。今回，術後 2 週間は同一のパスを用い， 2 週目で評価を行い，3 パターンのパスを用いることとした。【対象・方法】平成 16 年 3 月 1 日〜 9 月 30 日の間にパスを使用し た 21 例（男性 5 例，女性 16 例）で，手術時平均年齢 82 歳（69９4 歳）, Dynamic Hip Screw (4 例), Proximal Femoral Nail（17 例）を行った.【結果及び考察】運用実績は $90.5 \%$ で，パス導入前後での 車椅子・部分荷重開始時期は有意に短縮し, 全荷重開始時期は有意差を認めないものの短縮傾向を示し, 逸脱例は 0 例であった。当院のパスは，大半の患者に適応でき，早期荷重可能なバリアンスが少ないバラ ンスが取れたものである. 今後, 症例を重ねて在院日数の短縮など改善していく必要がある.

We evaluated patients with trochanteric fracture of the femur who were treated surgically and rehabilitated along our critical pathway. A total of 21 patients (5 males and 16 females) who underwent operative treatment were included. All patients were programmed to start partial weight bearing one week after operation. At two weeks postoperatively, we studied the radiographs and walking ability, and determined the time of starting full weight bearing. Nineteen patients (90.5\%) were treated along the critical pathway. Variance was minimal, and it was found that our critical pathway was useful for elderly patients with femoral trochanteric fracture.

Key words : critical pathways (クリティカルパス), femoral trochanteric fracture (大腿骨転子部 骨折), dynamic hip screw (ダイナミックヒップスクリュー), proximal femoral nail (プロキシマルフェモラルネイル)

は じめ に

クリティカルパス（以下 CP と省略する）の活用は 医療や看護の標準化と質の向上, チーム医療の確立, インフォームドコンセントの充実といつた面での効果 が明確になっている1)。しかし，大腿骨転子部骨折の CP はバリアンスが多いのが問題であり, 融通のきく $\mathrm{CP}$ を作成しなければバリアンスの症例が大多数となつ てしまう。荷重時期・程度は症例により変更すべきで あり，画一的な CP を行うべきではない22. そこで当 院では, 術後 2 週間は同一の CP を用い, 2 週間後に 評価を行い, 2 週間後より 3 パターンの CP を用いる
ことで, 標準化されつつ, バリアンスの少ない CP を 用いることとした（図1).

\section{対象および方法}

平成 16 年 3 月 1 日〜 9 月 30 日までに手術が行われ た症例で 21 例（男性 5 例，女性 16 例），手術時年齢 は 69〜94 歳（平均 82 歳）であった. Evans 分類で type 1 group 1 が 4 例, group 2 が 9 例, group 3 が 3 例, type 2 が 5 例で, Dynamic Hip Screw（以 下 DHS と省略する） 4 例, Proximal Femoral Nail （以下 PFN と省略する） 17 例を行った.

$\mathrm{CP}$ 導入前後の車椅子と荷重開始時期，バリアンス

\footnotetext{
* 佐賀県立病院好生館整形外科 Department of Orthopaedic Surgery Saga Prefectural Hospital Koseikan, Saga, Japan
} 


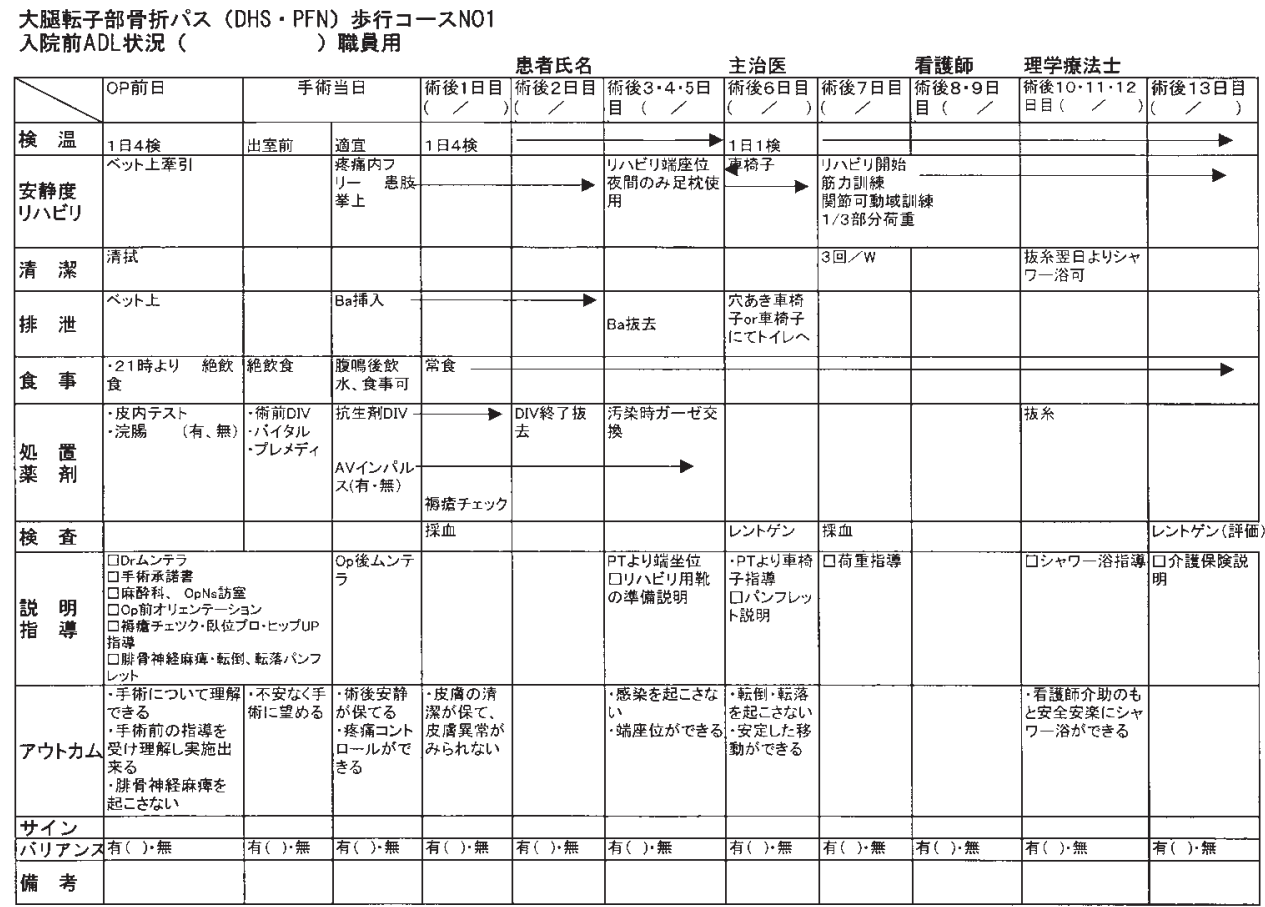

大煺転子部骨折パス (DHS・PFN) 歩行コースNO2

\begin{tabular}{|c|c|c|c|c|c|c|c|}
\hline$\gamma$ & 闌後14日目(3䓢目) ， ） & 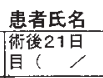 & 街後28日 & \begin{tabular}{l}
\multicolumn{1}{c}{ ゴール設定 } \\
術後35日 \\
目
\end{tabular} & 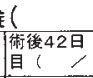 & 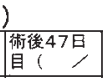 & 退 院 \\
\hline 検 温 & & & & & & & \multirow{15}{*}{ 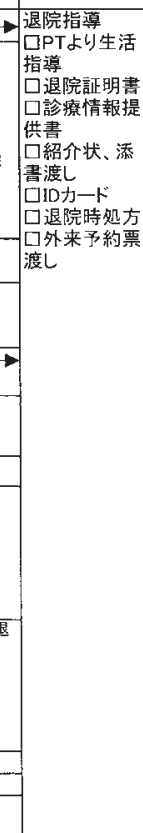 } \\
\hline \multirow{5}{*}{$\mid \begin{array}{l}\text { 安静度 } \\
\text { リハヘビリ }\end{array}$} & 回(1)全荷重歩行しても荖し支えない...全荷重步行 & 全荷重齿行 & 全渂重齿行 & 退院、転院 & & \multirow{5}{*}{ 退院、転院 } & \\
\hline & 口(2)部分荷重を理解でぎい...全荷重歩行 & 全荷重歩行 & 全荷重歩行 & 退院、䢂院 & & & \\
\hline & 口(3)部分荷重が方う少し...部分何重类行 & 全荷重歩行 & 全荷重歩行 & 全荷重歩行 & 退院、転院 & & \\
\hline & ロ(4)レンドンンにて異常を锱める…車椅子 & \multirow{2}{*}{ | } & \multirow[t]{2}{*}{ 全荷重歩行 } & \multirow[t]{2}{*}{ 全荷重齿行 } & \multirow[t]{2}{*}{ 全荷重步行 } & & \\
\hline & 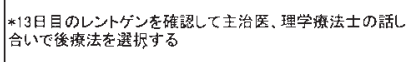 & & & & & & \\
\hline 清 潔 & シャヤー浴 & & & & & & \\
\hline 排 泄 & F-イLE & & & & & & \\
\hline 食 事 & 常会 & & & & & - & \\
\hline 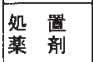 & & & & & & & \\
\hline 榆 查 & |レントゲン & レントゲン & レントゲン & レントゲン & |レントグン & レントダン & \\
\hline $\begin{array}{ll}\text { 説 } \\
\text { 明 } \\
\text { 指 }\end{array}$ & 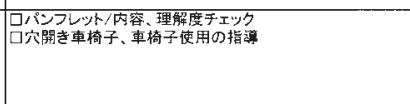 & 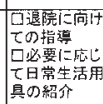 & & & & & \\
\hline アウトカム & 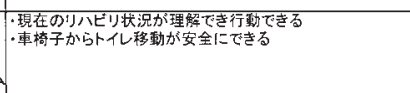 & 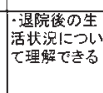 & 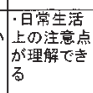 & & & \begin{tabular}{|l|} 
不案なく退 \\
院だきる
\end{tabular} & \\
\hline \#イン & L & 5 & t佂 & t) & F & 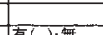 & \\
\hline 備 考 & & & & & & & \\
\hline
\end{tabular}

図 1 当院のクリティカルパス（医療者用） 術後 2 週間目で評価を行う（矢印）. 


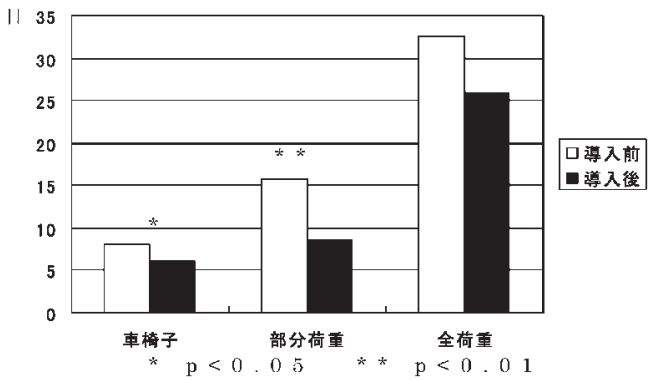

図 2 パス導入前後の車椅子・荷重開始時期 パス導入前後で車椅子, 部分荷重開始時期は有 意に短縮した．全荷重開始時期は有意差を認め ないものの, 短縮傾向を示した.

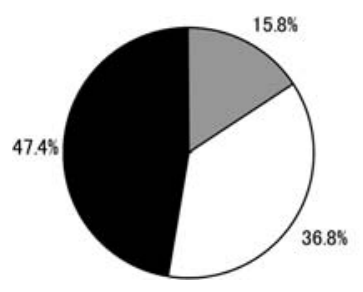

ロ6日目にバリアンス ロ7日目にパリアンス ロバリアンスなし

図 3 バリアンスの発生率 6 日目に車椅子移乗ができなかつた症例は $16 \%$, 7 日目に部分荷重ができなかった症例は $37 \%$ であった。

の発生率と運用実績について比較検討した。 なお, $\mathrm{CP}$ 導入前は平成 15 年 9 月 1 日〜平成 16 年 3 月 31 日までの症例とした。 なお，検定は Mann-Whitney 検定を用いた.

$$
\text { 結果 }
$$

運用実績は $90.5 \%$ で，2 例は転子下に及ぶ高度粉 砕骨折の為, 免荷期間を長めにする必要があり, CP より除外した。CP 導入前後での車椅子・部分荷重開 始時期は有意に短縮し, 全荷重開始時期は有意差を認 めないものの，短縮傾向を示した（図 2)。車椅子開 始が術後 6 日目に行われなかったバリアンス発生率は $15.8 \%$ ，部分荷重開始が術後 7 日目に行われなかつ た発生率は $52.6 \%$ であった（図 3 )。逸脱例は 0 例で
あった。

考察

8 割の症例が CP 通りに進むと良い CP と言われて いる2)が，今回，バリアンスの発生率は 5 割強であっ た.しかし，原因は連休・祝日・透析日がリハビリ開 始時期と重なってしまったことがほとんどであった. $\mathrm{CP}$ に乗せることが困難と言われる転子部骨折に対し て，バリハンスを半分に抑え， $\mathrm{CP}$ を導入可能であつ たということは十分に成果があったと言えよう.

$\mathrm{CP}$ 導入前後の車椅子・荷重開始時期を比較した. 改善点は車椅子, 部分荷重開始時期はともに個々の症 例での差がなくなり, 開始時期が短縮しており, 術後 リハビリが指示もれなくスムーズに行われたことを示 唆している. 従来の $\mathrm{CP}$ では荷重時期の設定を曖昧な 荷重時期設定で対応しているが，今回の CP では，厳 重な荷重時期を設定しつつ, 変更可能とし, バリアン スの発生を予防することが可能となつた. つまり当院 の $\mathrm{CP}$ は，大半の患者に $\mathrm{CP}$ を適応でき，早期荷重が 可能で，かつバリアンスが少ないバランスが取れたも のであると言えよう.

今後の課題として, 在院日数の短縮が必要となり, もつと早くから歩行するような $\mathrm{CP}$ や，転院後にも同 様の CP を用いることが可能な地域共有の CP を作成 する必要があると考えられる.

$$
\text { ま と め }
$$

当院では $\mathrm{CP}$ 途中に 3 パターンの荷重時期の中から 選択する事が可能な CP を使用した． CP 導入前に比 して歩行開始までの期間短縮が可能となつた．様々な 骨折の Type に対応可能な CP で, バリアンスの発生 も予防できた。

\section{参 考 文 献}

1）佛淵孝夫：整形外科におけるクリティカルパスの導入 と活用. 整形・災害外科, 47 : 421-426, 2004.

2) 中野哲雄 : 大腿骨頸部外側骨折手術のクリティカルパ 又. 整形・災害外科, $47: 637-642,2004$. 